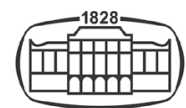

AKADÉMIAI KIADÓ

\title{
A Sandomierz penny of Vladislas the Ell-high (1305-1333) from the graveyard in Felsőzsolca, Hungary
}

\section{Archaeologiai Értesítő}

$146(2021) 187-196$

Dol:

$10.1556 / 0208.2021 .00008$

() 2021 The Author(s)

\section{Short communication}

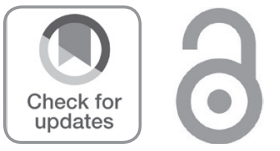

* Corresponding author:

E-mail: simonyie@hnm.hu

\author{
Borys Paszkiewicz ${ }^{1}$ (]) Erika Simonyi ${ }^{2 *}$ (]) \\ ${ }^{1}$ University of Wroclaw, Institute of Archaeology, Szewska 48, 50-120 Wrocław; \\ e-mail: borys.paszkiewicz@gmail.com \\ ${ }^{2}$ Magyar Nemzeti Múzeum, 1088 Budapest, Múzeum krt. 14-16. \\ Manuscript received: 7 May 2021 • Manuscript accepted: 7 June 2021
}

\section{ABSZTRAKT}

Felsőzsolca-Nagyszilváson az 1999-2000 között folyó feltárások során a 27. sírból előkerült egy hosszú ideig meghatározhatatlan 14-15. századi, baltikumi származásúnak vélt pénz. A sírban más melléklet nem volt, így keltezése is bizonytalan lábakon állt. Közel húsz év elteltével derült fény a pénz származási helyére az első ilyen veret ugyanis csak 2013-ban került elő Lengyelországban, Piotrówka erődjében. Napjainkig mindössze hat veretet ismerünk a típusból.

\section{KULCSSZAVAK}

középkor, 13-14. század,templom körüli temetô, pénz, lengyel, Sandomierz, korona, sas

\section{ABSTRACT}

The present paper seeks to examine a rare medieval coin from Poland, which was found in the medieval churchyard of Felsőzsolca in 1999. The place of origin of the penny was unkown for a long time, and the similar first specimens were found in the excavation on the hillfort of Piotrówka in Radom only in 2013. At present, we know as many as six such specimens.

\section{KEYWORDS}

Middle Age, $13^{\text {th }}-14^{\text {th }}$ centuries, churchyard, coin, Polish, Sandomierz, crown, Eagle

\section{THE SITE - THE MEDIEVAL CHURCH AND CHURCHYARD OF FELSŐZSOLCA}

Felsőzsolca is in Borsod-Abaúj-Zemplén county, on the north-east part of Hungary, $6 \mathrm{~km}$ to the east from Miskolc (Fig. 1). The site is located in the old bank of the river Sajó, on the Nagyszilvás mound, a residential area of the town. The church and the cemetery has been excavated by the Hungarian National Museum between $1999-2000^{1}$ with the support of the Municipality of Felsőzsolca.

Written sources referred to Felsőzsolca first in 1291. The church - named after St. Michael occurred for the first time in the papal tithe register between 1332-1335. In the $14^{\text {th }}$ century the village belonged to the Diósgyorr domain of the Paulite Order. In the $15^{\text {th }}-16^{\text {th }}$ century the owners were members of the lower and middle nobility. In consequence of the unceasing Turkish attacks and the ensuing epidemics the village became depopulated: in 1712 Felsözsolca was mentioned among deserted villages. The church had been in ruins when the delegate of the bishopric of Eger visited the "old catholic church" in the middle of the $18^{\text {th }}$ century. At that time only 49 people lived in the village - mainly Ruthenians (Transcarpathian Ukrainians) - who used the site as a cemetery. By the end of the $19^{\text {th }}$ century the church fell into oblivion and Nagyszilvás was used as a plum orchard.

During the excavation we found the remains of St. Michael church and 189 graves of the churchyard (Fig 2). Only the bottom of the bulding's foundation-ditch has survived to our

${ }^{1}$ Simonyi 2004, 161-197; Simonyi 2005, 305-314. 
time. The outer length of the church is $16.5-17.5 \mathrm{~m}$, the nave is about $12 \mathrm{~m}$ long. The sanctuary was semicircular and raised. The walls of the church were made from broad-stones. By reason of its style and measurement the church could be dated to the $12^{\text {th }}-13^{\text {th }}$ century. It is likely that the mentioned church was not the first religious structure, because its foundation cut some graves, for example No. 163 that is dated from the $11^{\text {th }}-12^{\text {th }}$ century by a pair of S-ended hair-ring.

The set-up of the churchyard is similar to the rural cemeteries of the period $\left(13^{\text {th }}-16^{\text {th }}\right.$ century), as most of the graves and also the richest ones were on the south side. Burials are oriented mostly to the West but two exemptions (Nos. 28 and 49 ). From the $14^{\text {th }}$ century on, the dead were mainly buried in wooden coffins and with their arms crossed.

At least $8 \%$ of the burials contain jewellery, dress ornaments or grave-goods. Remains of the $16^{\text {th }}-17^{\text {th }}$ century woman attire (pearly coronets, silk bodices) were found in graves 162 and 180. Superstitious habit - probably connected with witchcraft - could be the reason of burying jug and fragments of a pipe with the old woman of grave 129. In this grave a Bavarian penny of Charles Albert (1726-1745) was found.

Close to the western façade of the church, in grave 27, containing remains of a child, a medieval coin of unknown origin was found. The depth of the grave was $97 \mathrm{~cm}$ from the present ground surface. The lower part of the skeleton was destroyed by the irregular buried ( $\mathrm{N}-\mathrm{S}$ orientated) grave No. 28. (Fig. 3). Only the skull and the upper arm were intact. The coin was found close to the jaw bone, and it was unidentified for years (Fig. 4). ${ }^{2}$

\section{THE COIN}

The only medieval coin found in the graveyard turn out to be a Polish penny from the fourteenth century (Fig. 4).

- Obv.: in the margin, $+\mathrm{DED} \Lambda[\mathrm{RIV}] \mathrm{S} \circ$; in the field, a large letter $\mathrm{S}$ with a large pellet in the middle. Borders of pellets.

- Rev.: in the margin, $+\mathrm{S} \Lambda \mathrm{DDO}{ }^{\circ} \mathrm{MIRI}$; in the field, the eagle's head left, crowned with a low, open crown surmounted with three lilies. Borders of pellets.

- Weight $0.26 \mathrm{~g}$, diameter 11.5-12.2 mm.

This coin is absent from numismatic catalogues including the newest one, by J. G. Frynas. ${ }^{3}$ As a Polish coin, such a penny was discovered in Poland only in 2013, and it was published for the first time in 2018. Mateusz Bogucki and Maciej Trzeciecki have found two such specimens in the excavation on the hillfort of Piotrówka in Radom (that is, early medieval Radom). ${ }^{4}$ At present, we know as many as six such specimens. The Polish specimens known are as follows:

${ }^{2}$ We would like to thank Dr. Csaba Tóth, the numismatist of the Hungarian National Museum, who first identified the coin, for his help.

${ }^{3}$ Frynas 2015, 246-249.

${ }^{4}$ Bogucki-Trzeciecki 2018, 275-287.
1. Obv: in the margin, $\circ+[\circ \mathrm{DE}] \mathrm{D} \Lambda \mathrm{RIV}[\mathrm{S}]$; in the field, a large letter $S$ with a large pellet in the middle, borders of pellets. Same die as No. 5 .

Rev.: in the margin, $+S[\Lambda \mathrm{D}] \mathrm{DOMIRI}$; in the field, the eagle's head left, crowned with a low, open crown surmounted with three lilies. Borders of pellets.

Chipped, 0.15 g, $12 \mathrm{~mm}$. Find: Radom-Piotrówka hoard.

2. Obv.: [+DE]D $\Lambda$ RIV[S]. Rev.: +oS $\Lambda$ [DDOM]IRI. 0.27 g, 12.5 mm. Find: Radom-Piotrówka hoard.

3. Obv.: $+{ }^{\circ} \mathrm{DED} \Lambda \mathrm{RIV}[\mathrm{S}]$. Rev.: $+\mathrm{S} \Lambda[\mathrm{D}] \mathrm{DO}{ }^{\circ} \mathrm{MIRI}$; same die as No. 5 and the Felsőzsolca specimen.

Corroded, 0.22 g, 12.7 mm (a). Find: Sandomierz Mariacka hoard, 2014.

4. Obv.: $+\mathrm{D} \in[\mathrm{D} \Lambda \mathrm{R}] \mathrm{IVS} \circ$; same die as the Felsőzsolca specimen. Rev.: $+\mathrm{S}[\Lambda]$ DDOMIR。.

0.33 g, $12.7 \mathrm{~mm}$ (b). Find: Lublin, $2017 .^{6}$

5. Obv. ${ }^{\circ}+{ }^{\circ} \mathrm{DED} \Lambda \mathrm{R}[\mathrm{IV}] \mathrm{S}$; same die as No. 1. Rev. [+] SADDO ${ }^{\circ} \mathrm{MIR}[\mathrm{I}]$; same die as No. 3 and the Felsőzsolca specimen.

Broken, $1 / 4$ is missing. $0.27 \mathrm{~g}, 12.6 \mathrm{~mm}$. Find: Miechów, 2012. ${ }^{7}$

Thus the Felsőzsolca specimen's obverse is set in a die-chain consisting of almost all known specimens but No. 2 (Fig. 5).

The legend indicates clearly that this is denarius Sandomirie or Sandomiriensis, i.e. a "penny of Sandomierz", and refers to Sandomierz, an important political and commercial centre in south-eastern Poland (Fig. 6). The name of any ruler is absent from the coin, though. Also the obverse type, a bold letter $S$, does not indicate a ruler since there was no ruler whose name would begin with $S$ in Sandomierz in the fourteenth century. Therefore, the letter $S$ must stand for Sandomierz again. The letter always has a large pellet set in its middle. Such a form has no analogy in Polish epigraphy of the fourteenth century. ${ }^{8}$ On the other side, the crowned eagle's head with neck and four feathers - one can say, an eagle's bust - seems to be a part of the White Eagle, the coat of arms of the king of Poland. But the White Eagle occurs also on Sandomierz seals, together with other royal symbols. On the great seal (dated recently to the first half of the fourteenth century), the shield and helmet of the king are placed upon the city gate and surrounded with the legend s[igillum or signum] REGIS POLONIE ET CIVITATIS SANDOMIRIE (Fig. 7). On the minor seal the king himself is shown facing enthroned, with the legend s[igillum] Minvs CIVITATIS SANDOMIRIE, and on the seal of the city court (ława), the eagle's upper half is accompanied with: s[igillum] SCABINORVM SANDOMIRIENSIVM $^{9}$ (Fig. 8). The last case, although being a bit later, is particularly worth of our attention as it shows a part of the eagle and not the whole one, despite the space was large

\footnotetext{
${ }^{5}$ Michał P. Grabowski, pers. comm.

${ }^{6}$ Michał P. Grabowski, pers. comm.

${ }^{7}$ Paweł Micyk's excavation; coin study by Roksana Wawrzczak and Borys Paszkiewicz.

${ }^{8}$ TrelińsKa 1991, 38.

${ }^{9}$ Gumowski 1960, 192-194, nos 382-384.
} 


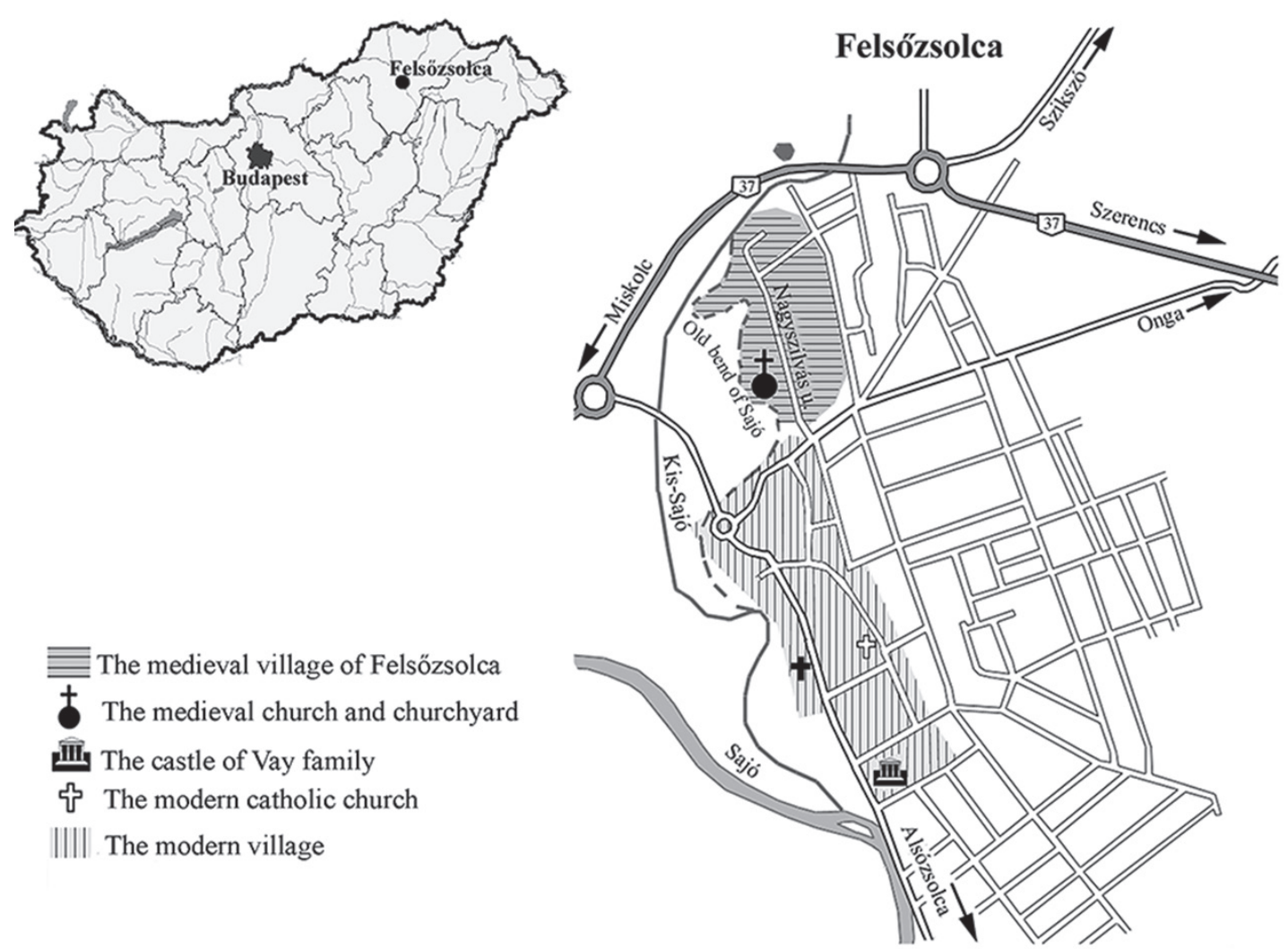

Fig. 1. Felsőzsolca-Nagyszilvás, the site

1. kép. Felsőzsolca-Nagyszilvás, a lelőhely

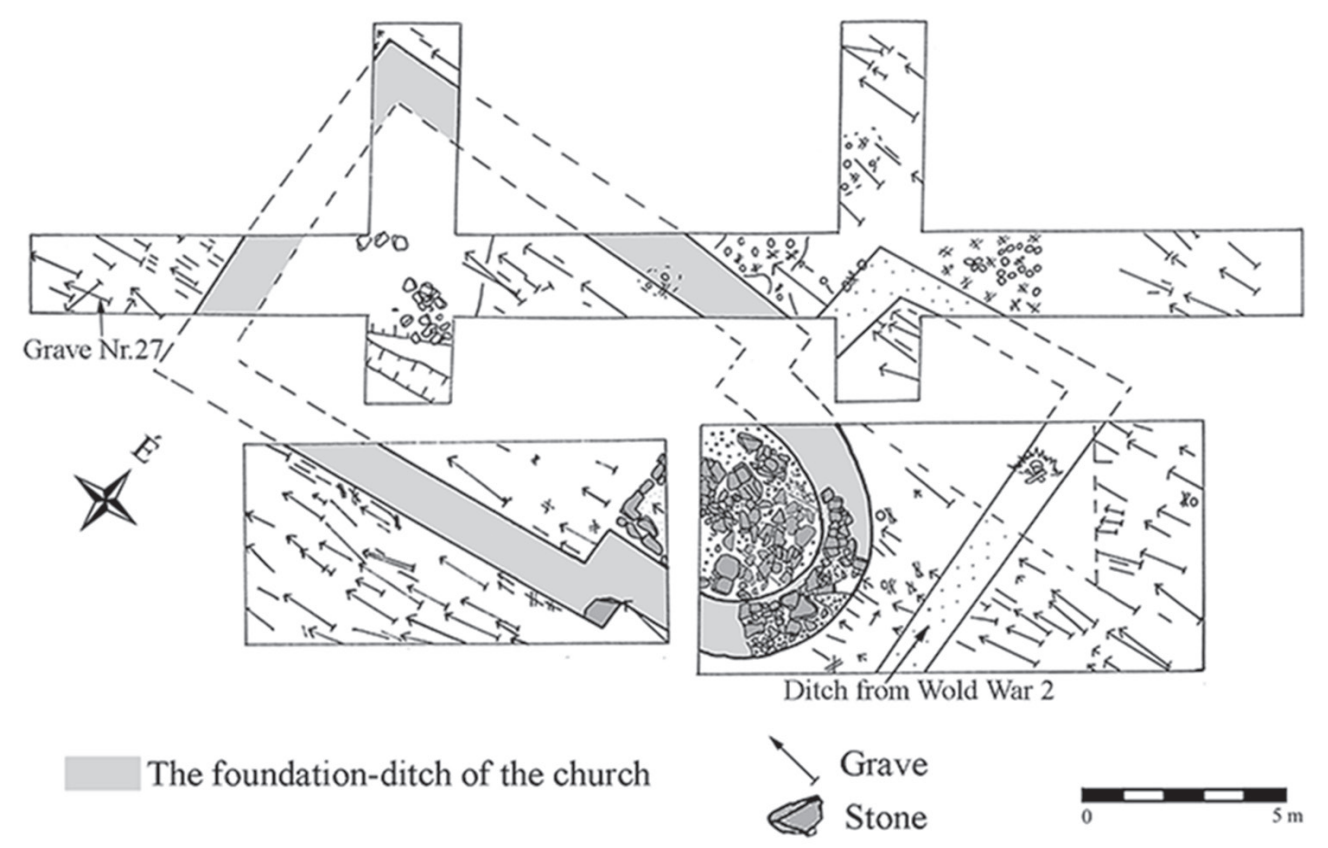

Fig. 2. The groundplan of the excavation

2. kép. A templom és a temető, ásatási összesítő rajz 


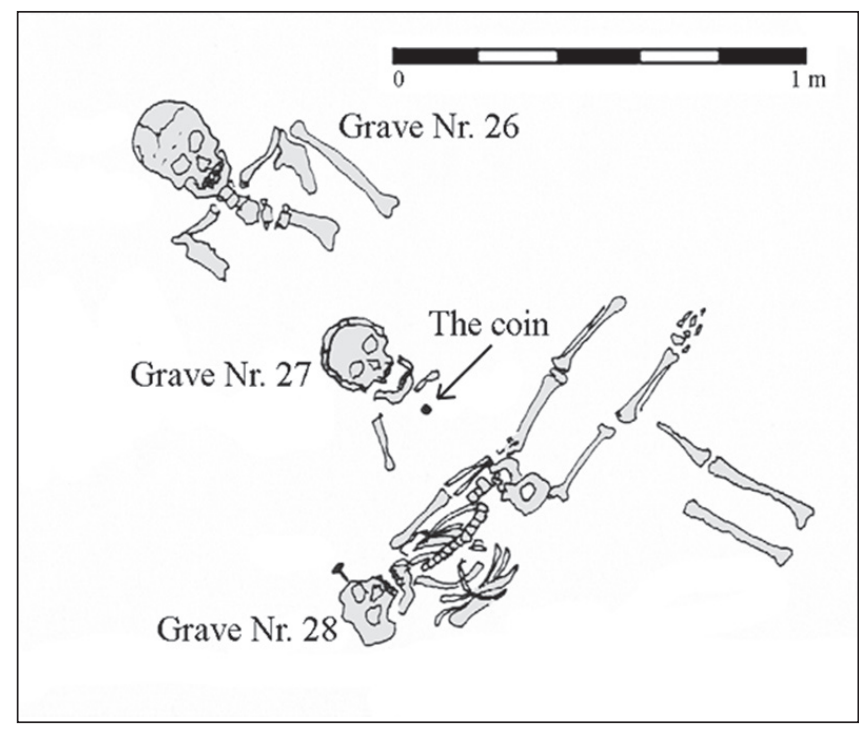

Fig. 3. Felsőzsolca-Nagyszilvás Grave No. 27.

3. kép. Felsőzsolca-Nagyszilvás, a 27. sír

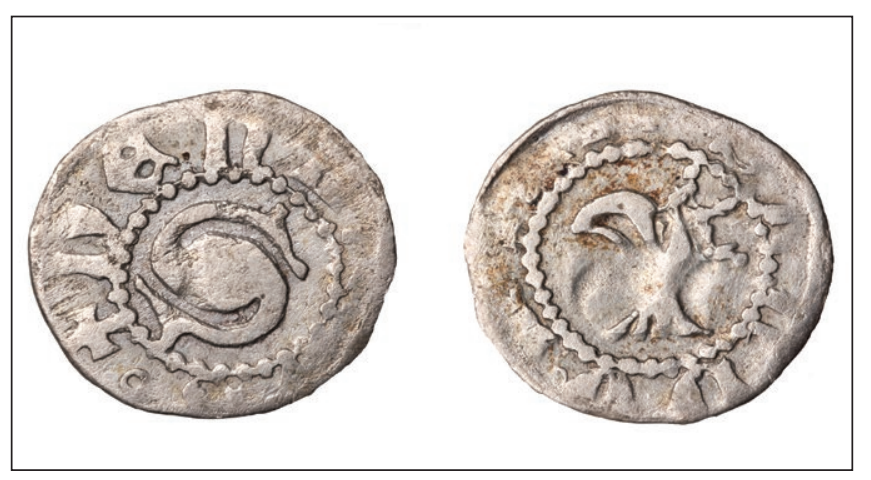

Fig. 4. Felsőzsolca-Nagyszilvás, the Sandomierz coin

4. kép. Felsőzsolca-Nagyszilvás, a 27. sírban talált Sandomierz érem

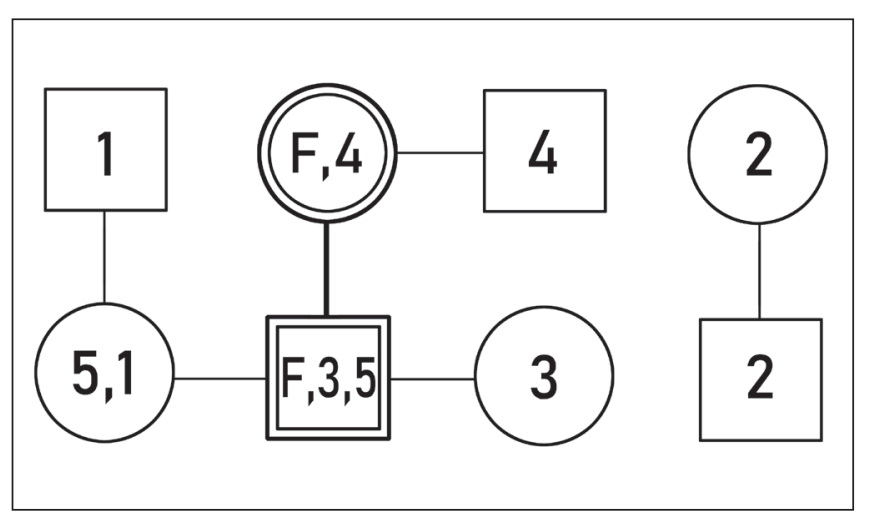

Fig. 5. Die links of Sandomierz pennies. Rings: obverses; squares: reverses; 1 to 5 : specimens from the Polish finds according to the list; F: the Felsőzsolca specimen (drawing by Nicole Lenkow)

5. kép. A Sandomierz érmék verôtövének kapcsolatai: kerek: előlap; négyzetek: hátlap; 1-5: a lista szerinti példányok a lengyel leletekből; F: a felsőzsolcai példány

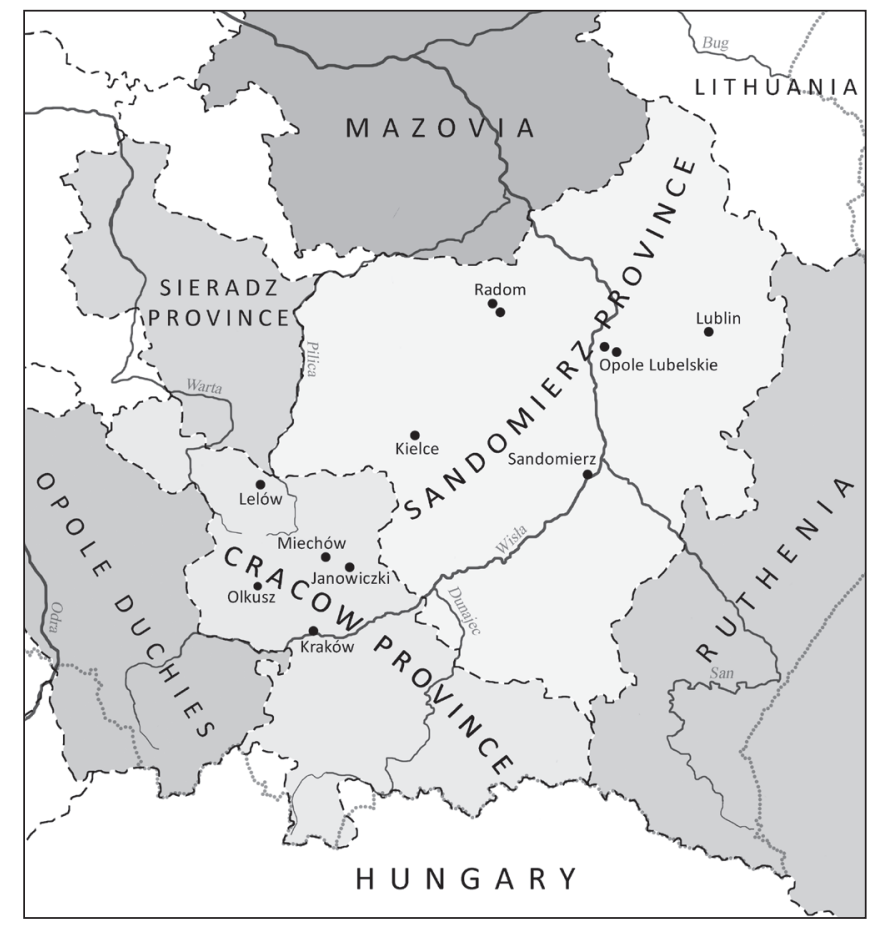

Fig. 6. Location map of Polish sites discussed in the text in relation to political divisions from c. 1320 (drawing by Nicole Lenkow)

6. kép. A lengyel lelőhelyek térképe az 1320 körüli politika viszonyokra

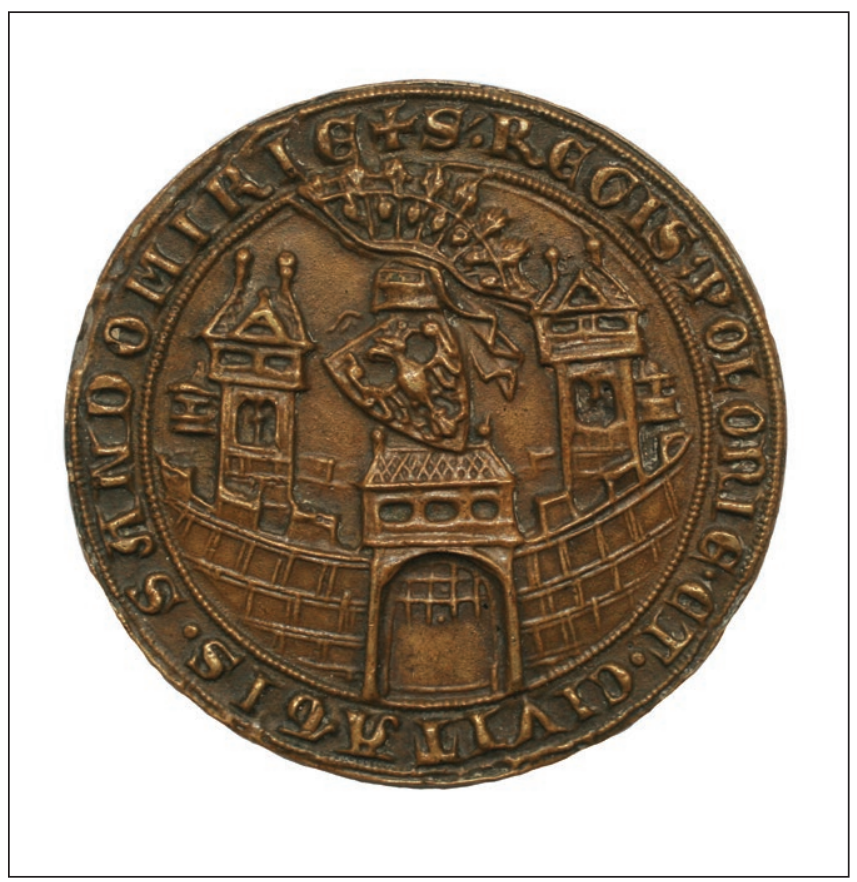

Fig. 7. The Great Seal of the city of Sandomierz, c. 1300?, possibly recut in 1343. Cast bronze copy, $19^{\text {th }}$ century (Jagellonian University, Department of Auxiliary Historical Disciplines, no. D 336, photograph provided by courtesy of Professors Paweł Stróżyk and Zenon Piech)

7. kép. Sandomierz nagypecsétje 1300 körül, valószínúleg 1343-ban újravésve. Öntött bronz, 19. századi másolat 


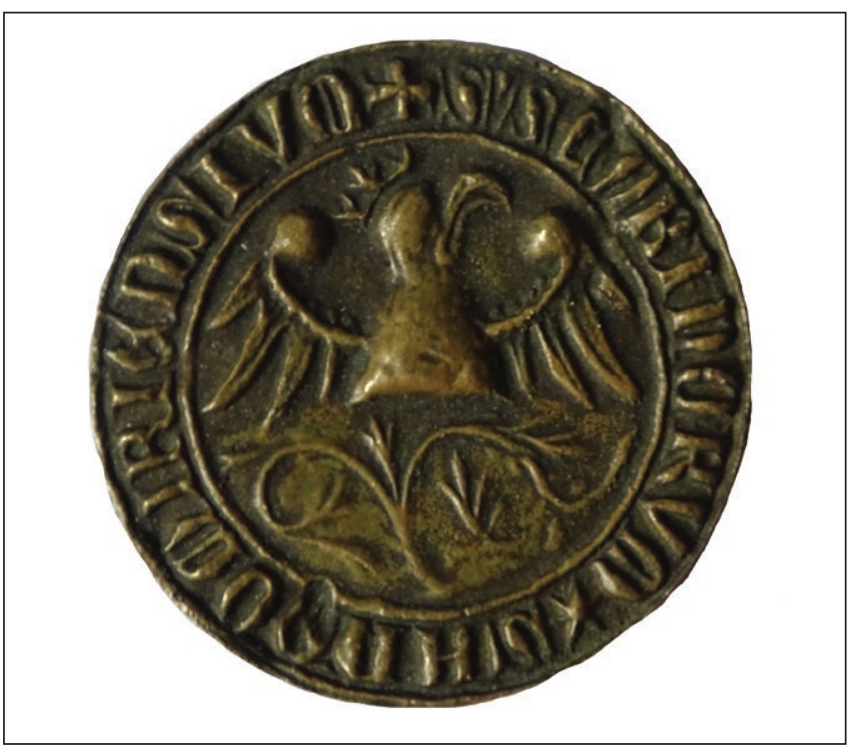

Fig. 8. The seal of the city court (ława) of Sandomierz, 1336(?) Cast bronze copy, $19^{\text {th }}$ century (Jagellonian University, Department of Auxiliary Historical Disciplines, no. D 337, photograph provided by courtesy of Professor Zenon Piech)

8. kép. Sandomierz városi bíróságának (ława) pecsétje 1336-ból(?). Öntött bronz, 19. századi másolat

enough to depict it in a whole. We do not know the legal basis of using royal symbols on the city seals but this certainly reflects close ties between the king and the city elite. ${ }^{10}$ But who was the king from the Sandomierz seals and was he identical with the issuer of the denarius Sandomiriensis? Marian Gumowski believed that the great seal was produced during Vladislas the Elbow-high's times (1305-1333, the king from 1320) but Mieczysław Rokosz suggested rather Casimir the Great (1333-1370). ${ }^{11}$ Only recently, Piotr Stróżyk observed that the crest on the seal is adorned with linden leaves that were emblems of kings of Bohemia, especially Wenceslas II and John the Blind, of whom the former ruled Sandomierz in 1292-1305. What is more, the irregularities in the legend suggest that it might be re-engraved with the word POLONIE instead of BOEMIE. ${ }^{12}$ Eventually, this scholar suggests that the great seal was originally produced in 1297-1300, after the Bohemian coronation of Wenceslas and before his Polish one, and possibly recut in 1343 .

However, a crowned eagle's heads or busts occur on other Polish coins from the last decades of the thirteenth and the first two decades of the fourteenth century, in Silesia, Opole Province, Greater Poland, Łęczyca, Sieradz and Cracow Provinces (Fig. 9). It is difficult to say why it was not a whole figure of an eagle there but certainly it did not result from a lack of space. Possibly it was so in order to discern these coins from other ones, showing a whole eagle. Therefore, the reducing an eagle to its bust might be caused by a purely practical reason resulting from the needs of the monetary market. Anyway, a crowned eagle's head on a Polish coin may suggest its issuer being a king or a pretender to the crown of Poland. ${ }^{13}$ We have to do with a Sandomierz coin struck when the local city elite emphasized their ties with a king of Poland, but not necessarily with the ruling prince.

The province of Sandomierz became a princely appanage in 1146. Starting from 1228, its rulers styled themselves the dukes of Sandomierz, duces Sandomirie. ${ }^{14}$ In the period of question, they were:

1. Vladislas the Ell-high, 1290-1292,

2. Wenceslas II of Bohemia, 1292-1305 (king of Poland from 1300),

3. Vladislas the Ell-high, 1305-1333 (king of Poland from 1320) and

4. King Casimir the Great, 1333-1370.

Polish dukedoms in the thirteenth century were not fiefs but shares in general power belonging to the dynasty, and the duke of Cracow, sometimes named the grand duke, was primus inter pares among the members of the dynasty. This made the individual rulers the owners of minting rights in their lands. The re-centralization of the restored Kingdom in the fourteenth century consisted mainly in gathering individual duchies in the hands of the king, and only in sporadic cases taking over the sovereignty over local dukes. Until recently, traces of particular coinages in the fourteenth century were few and scholars believed that the coinage centralization in Cracow went relatively quickly, leaving only ephemeral cases of separate coin issues, like in Poznań and Kalisz. Only discoveries of the two recent decades - mostly thanks to the use of metal detectors - showed a surprising diversity of local pennies, a large part of them being anonymous and difficult to interpret.

Vladislas the Ell-high's elder brother, Duke Lestek the Black of Cracow, Sandomierz and Sieradz (1279-1288), re-chartered Sandomierz in 1286, after the town had been heavily devastated by the Mongol invasion. Lestek entrusted the city and its vogt Witig with minting ducal coinage for the Duchy of Sandomierz. ${ }^{15}$ It was the first known endowment of a Polish town with minting rights. Coins of Sandomierz, however, remained unknown for a long time. Only in 2000, it was observed that two types of anonymous, two-sided pennies might be attributed to the reign of Wenceslas II in Poland (1291-1305), one of them being found mostly around Cracow, and the other one, occurring east of this city, couldhave been struck in Sandomierz. ${ }^{16}$

Vladislas the Ell-high while fighting for Cracow in 13041306, was supported by an Upper-Hungarian magnate, Aba Amadé. Having seized Sandomierz in 1305, Vladislas deposed Witig who sided with Bohemians. The duke appointed

\footnotetext{
${ }^{10}$ Conf. the case of the town of Kazimierz: Рiech 2008, 814-815.

${ }^{11}$ Gumowsкi 1960, loco citato; Roкоsz 2002.

${ }^{12}$ STRÓżYK 2017, 112-113.
}

\footnotetext{
${ }^{13}$ Paszkiewicz 2019.

${ }^{14}$ Teterycz 2001, 61.

${ }^{15}$ ŻMUdZKi 2000, 423-425; PAsZKiEWicz 2008, 770.

${ }^{16}$ PaszKienicz 2000.
} 
his own allies, Marek and his son Rupert, as the new vogts of Sandomierz. The vogt of Sandomierz created in 1305, Marek (ii), was a son of another Marek (i), a former moneyer in Cracow who died by $1302 .{ }^{17}$ At uncertain time, possibly at the end of 1307, after Marek (ii)'s death, Witig returned to power in the city. When Aba was killed in Košice (Kassa) on 5 September 1311, Sandomierz probably initiated or at least joined the rebel of south-Polish cities against Duke Vladislas. ${ }^{18}$ On 31 October 1311, the duke again deposed the vogts of Sandomierz, Witig and Siegfried, for committing betrayal. At the same time the duke restored this office to Rupert and Marek (iii), the sons of Marek (ii). ${ }^{19}$ After Vladislas became king in 1320, he still styled himself dux terre Sandomiriensis among other titles of power of particular Polish lands in his documents, although the duchy of Sandomierz evolved into an administrative unit, a land (ziemia, terra) that would be called voivodeship (palatinatus, województwo) in the fifteenth century. ${ }^{20}$ The duchy-land of Sandomierz kept its local officials as relics of its autonomy: a voivode, a judge with his assistant and a scribe. ${ }^{21}$

There are no written records on the activity of the Sandomierz mint. Among coins of Vladislas the Ell-high displaying his royal title (hence minted in 1320-1333), there are too many types of pennies of the southern part of the kingdom to be produced in the Cracow mint only. We had no renovatio monete in South Poland then and, consequently, the coin types should be stabilised. The mint names are not indicated on these coins, though. Certain types, according to their find occurrence, may be distributed between Cracow and Sandomierz mints. This may indicate that the Sandomierz mint still worked after Vladislas's coronation. ${ }^{22}$ However, the distribution of finds is not certain as an indicator of coins' origin because the area of Cracow is generally worse examined in archaeological terms than Sandomierz, Radom or Lublin. Cracow itself was and still has been excavated mostly by archaeologists interested in monumental architecture (particularly early medieval one), who pay less attention to later medieval single coin finds. What is more, the results of the largest excavations on the Cracow Main Market Square (conducted 2005-2010) have not been published yet, like results of the series of less attractive researches in the city.

The name of Cracow, although it was the capital town of the whole restored kingdom, did not occur on coins but one exception. This is the penny, discovered in 2010, with a helmet and Vladislas's paternal arms (the so-called Kuiavian arms: half-lion and half-eagle crowned) surrounded by the legends: WLODZLAMON - CRACOVIENSES, i.e. Wlodizlai mo-

\footnotetext{
${ }^{17}$ BIENIAK https://www.ipsb.nina.gov.pl/a/biografia/marek-1307 (accessed: 6 Oct 2019).

${ }^{18}$ JASIŃSKI 2018, 133.

${ }^{19}$ Wyrozumski 1992, 208.

${ }^{20}$ Teterycz 2001, 71-72.

${ }^{21}$ URZĘDNICY 1990, 12-13.

${ }^{22}$ Paszkiewicz 2008.
}

neta Cracovienses (Fig. 10). ${ }^{23}$ The plural form Cracovienses was certainly patterned upon the Prague groschen legend (Grossi Pragenses). Because the royal title is missing from the coin, it was certainly struck before Vladislas's coronation in 1320. NB., the distribution of these coins (two finds from the Opole Lubelskie area and two from Radom, all in the Sandomierz Province) speaks paradoxically for their Sandomierz origin. This makes us realize that even four single finds are not enough to infer a coin's origin, at least in the case of Cracow and Sandomierz.

The analogy to the Cracow penny helps us to make the abbreviated Sandomierz legend complete as denarius Sandomiriensis. It might be doubtful, however, that on this basis one could guess the simultaneity of both coins, because the weight of Sandomierz pennies (presumably about $0.27 \mathrm{~g}$, i.e. $12 \times 60=726$ from the Cracow mark) is clearly lower than the Cracow one $(0.34-0.42 \mathrm{~g}$, i.e. less than $12 \times 48=576$ from the mark). We can see that - unlike in Cracow - the mint town of Sandomierz is emphasized not only in the legend of the relevant coin but also in the obverse type (the monogram $S$ ) whereas the duke is almost absent from it, being referred to only with his reduced emblem (the eagle's head) and even this also can be interpreted alternatively as a part of Sandomierz's seal.

The finds from Lublin and Miechów, like the Felsőzsolca one, are single and we know nothing about their archaeological context. The hoards from Radom Piotrówka (2013) and Sandomierz Mariacka street (2014) provide us with a numismatic context of this coin type. The Radom Piotrówka hoard, hidden by $1350,{ }^{24}$ was roughly listed by M. Bogucki and M. Trzeciecki. Apart from several Bohemian coins, groschen and parvi of Wenceslas II and John the Blind (variants have not been indicated), there are two dozen of Polish pennies. Most of them were coins of the Helmet/eagle type (Frynas P.11.5), usually regarded as anonymous and attributed to Vladislas the Ell-high. ${ }^{25}$ Only recently, an initial letter of the name 'Kazimirus' was observed in legends on several examples of this type. For this reason, the coin has been reattributed to King Casimir the Great (1333-1370), and not at the very beginning of his rule but some time later. ${ }^{26}$ According to further, still unpublished studies, this coinage might begin in the thirteen-forties.

\footnotetext{
${ }^{23}$ Paszkiewicz 2010 (the coin was found in the Opole Lubelskie area). The legends are supplemented with three other specimens: Warszawskie Centrum Numizmatyczne, Sale 50, 2012, No. 12 (unprovenanced); Bogucki 2013, 43 (Radom, 2012) and M. Bogucki pers. comm. (Radom, 2013).

${ }^{24}$ According to the archaeologists, the existence of the Piotrówka castle in Radom had been terminated by a fire in the middle of the $14^{\text {th }}$ century (BoguCKI-TrZeciecki 2018, 289). The region of Radom was certainly devastated by the Lithuanian attack exactly in 1350 (РТАK 2015). It is not clear why the archaeologists do not take this fact into consideration. As a consequence of the devastation, King Casimir relocated the town of Radom to a new place and chartered it anew, probably in 1360 (Wyrozumska 1961, 86).

${ }^{25}$ Bogucki-Trzeciecki 2018, 281-282.

${ }^{26}$ MiazGa-Paszkiewicz 2019, 145-147.
} 


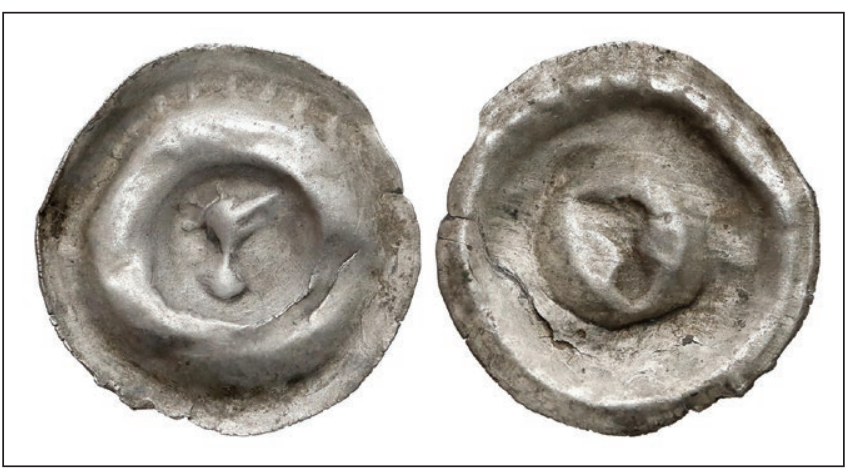

Fig. 9. A bracteate from the Cracow or Sandomierz province, probably of Vladislas the Ell-high (1305-1333). Unprovenanced, weight $0.155 \mathrm{~g}$, diameter $14.5 \mathrm{~mm}$ (photograph: Gabinet Numizmatyczny Damian Marciniak, Sale 11, 6-9 June 2020, lot 127)

9. kép. Brakteata Krakkó vagy Sandomierz tartományból, valószínúleg I. Łokietek Ulászlóé (1320-1333). Ismeretlen lelőhely, súly: 0,155 g, átm.: 14,5 mm

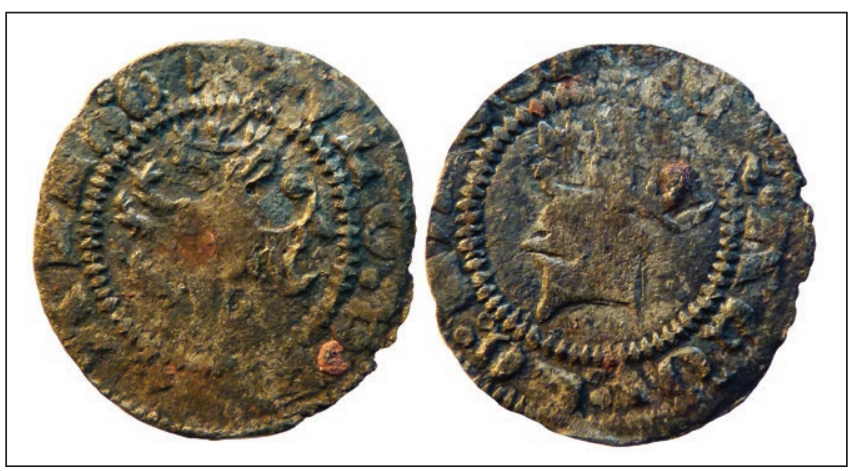

Fig. 10. Vladislas the Ell-high's penny with the name of Cracow. Radom, Piotrówka hillfort, excavated in 2012 (photograph provided by courtesy of Professor Mateusz Bogucki)

10. kép. I. Łokietek Ulászló érme Krakkó nevével, Radom, Piotrówka erőd, 2012-es ásatás

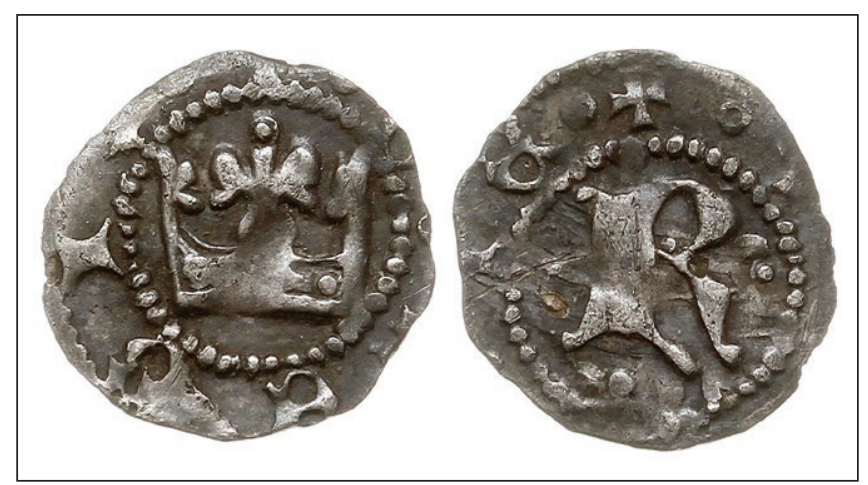

Fig. 11. The Crown/R penny, probably struck in Sandomierz after 1320. Unprovenanced, weight $0.26 \mathrm{~g}$, diameter $11.2 \mathrm{~mm}$ (Photograph: Warszawskie Centrum Numizmatyczne, Sale 55, 23 November 2013, lot 113)

11. kép. A korona/R érme, valószínúleg Sandomierzben verték 1320 után. Ismeretlen lelőhely, súly: 0,26 g, átm.: 11,2 mm
The Sandomierz Mariacka street hoard is much smaller (five pennies) and consists of disputable coins: ${ }^{27}$

1. Vladislas the Ell-high as the king (1320-1333), a penny with a profile head and the eagle shield (Frynas P.11.9); ${ }^{28}$ no traces of circulation;

2. The Sandomierz penny as above, No. 3: S/Eagle's bust; irregularly struck and a bit worn;

3. The penny of Crown/R type, attributed to Casimir the Great (1333-1370) till now (Frynas P.12.6); ${ }^{29}$ chipped;

4-5. Two pennies of Eagle/crown I type, attributed to Przemysł II (1295-1296) till now (Frynas P.GrP.6.1); heavily worn. ${ }^{30}$

Only one coin, showing the name of King Vladislas (No. 1), was struck certainly under the reign of Vladislas the Ell-high between 1320 and 1333, but it is not certain whether it was in Cracow or Sandomierz. The registered finds of such coins are: Janowiczki near Miechów, the Kielce area, Radom (several specimens) and Sandomierz. The list is certainly incomplete and - at present - suggests again the Sandomierz origin of this coin. ${ }^{31}$ Most probably, this coin was struck in the last years of Vladislas because a very similar obverse was used to strike an early penny of his son, Casimir. ${ }^{32}$ It is important to note that this is the best-preserved coin in the hoard.

There were no coins with the name of Casimir in the Sandomierz Mariacka find. All the other coins were anonymous there. However, very rare pennies of the Crown/R type (Fig. 11) are attributed to Casimir the Great, and this might be true because these coins are exceptionally small (c.12 mm, $0.21-0.26 \mathrm{~g}$ ) and there is a record that in 1337/8, King Casimir introduced larger pennies in the Cracow and Sandomierz provinces, ${ }^{33}$ and these were certainly coins of $c .14 \mathrm{~mm}$ diameter. The monogram $R$ may stand for rex. We do not know, however, why the Crown/R type was absent from the Radom Piotrówka hoard, and also from the set of single coins collected from that site, although it was found alone in another locality nearby (and also singly in Miechów and Olkusz, as well as in the Sandomierz Mariacka hoard). The distribution of finds may suggest their Sandomierz origin but this supposition is far from certain.

The last type from the Sandomierz Mariacka hoard (Frynas P.GrP.6.1), represented by two worn specimens there, is particularly difficult to determine. Previous hypotheses about its origin ${ }^{34}$ must be rejected because of the distribution of recent finds. Its unusual and early form as well as the

${ }^{27}$ I am much indebted to Mr. Piotr Chabrzyk who works on coins from Olkusz, and to Mr. Michał P. Grabowski who works on the Sandomierz Mariacka hoard, for their reports.

${ }^{28}$ Paszkiewicz 1986, 37-38, Type 7.

${ }^{29}$ STRONCZYŃSKi 1885, 28, No. 4a.

${ }^{30}$ StroncZyŃski 1885, 28-29, No. 4-bis; PAszkiewicz 2002b.

${ }^{31}$ See PAszKIEwicz 2002a.

${ }^{32}$ The coin appeared in December 2020 and has not been published yet.

${ }^{33}$ KIERSNOWSKI 1968, 181.

${ }^{34}$ Paszkiewicz 2002b. 
Italian style still speak for an early date. We cannot guess, though, where it was minted.

To sum up, therefore, the Sandomierz hoard was hidden at the beginning of the reign of Casimir the Great, soon after 1333. This suggests that the penny with the name of Sandomierz, was struck during the reign of Vladislas the Ell-high.

The penny with $S$ represents the unique name of the city, while it completely lacks the name and title of a king or duke. So it had to come out in special circumstances. These conditions would be best suited by Sandomierz's rebellion against Vladislas the Ell-high in the autumn of 1311. At the same time, the unique fact that such a penny found its way to Hungary and - as a unique medieval coin - at the Felsözsolca graveyard, suggests that it was brought by a person participating in the support of Aba Amadé for Duke Vladislas. This would make, however, the issue period of our coin only one or two months long, whereas the Sandomierz penny, although extremely rare, spread throughout the Duchy of Sandomierz and even Hungary. It is more likely then, that the connection between this issue and the city's rebellion was not so close and it was only the suppression of the rebellion that had caused the name of Sandomierz to disappear from the coins minted in that city. In this case, the Felsözsolca coin should be dated to the period 1307-1311 when the city of Sandomierz only reluctantly recognized Vladislas the Ell-high's sovereignty. On the other hand, however, the Sandomierz and Radom hoards allow us to assume that the coin is about ten years younger. For now, we have no grounds to resolve this dilemma.

\section{BIBLIOGRAPHY}

BIENIAK, JANUSZ

Marek (brak danych - ok. 1307). In: Internetowy Polski Słownik Biograficzny, https://www.ipsb.nina.gov.pl/a/biografia/marek1307 (accessed 6 Oct 2019).

Bogucki, Mateusz

2013 Przynależność terytorialno-ekonomiczna średniowiecznego Radomia w świetle źródeł numizmatycznych. In: Buko, A.Główka, D.-Trzeciecki, M. (eds): Ziemia niczyja - ziemia nieznana. Schyłek starożytnosci i średniowiecze na ziemiach między Wisłą a Pilicą. Warszawa, 37-46.

Bogucki, Mateusz-Trzeciecki, Maciej

2018 DENARIVS SANDOMIRI $\mathrm{z}$ radomskiego grodu. In: Nowakiewicz, Z.-Trzeciecki, M.-Błaszczyk, D. (eds): Animos labor nutrit. Studia ofiarowane Profesorowi Andrzejowi Buko w siedemdziesiątą rocznicę urodzin. Warsaw, 275-287.

Frynas, Jedrzej GEORGE

2015 Medieval Coins of Bohemia, Hungary and Poland. London.

GuMOWSKI, MARIAN

1960 Najstarsze pieczęcie miast polskich XIII i XIV wieku. Toruń.

JASIŃSKI, TOMASZ

2018 Handel miedzią węgierską a restytucja rządów Władysława Łokietka w Polsce (1304-1312) (Hungarian copper trade and the restitution of Ladislaus the Short's rule in Poland [13041312]). Roczniki Historyczne 84, 93-138. DOI: http://dx.doi. org/10.12775/RH.2018.04

KIERSNOWSKI, RYsZARD

1968 Data i kształt reform monetarnych Kazimierza Wielkiego, część I. Wiadomości Numizmatyczne 12, z. 3-4, 153-189.
Miazga, Beata-Paszkiewicz, Borys

2019 The Metal Content of Selected Polish and Brandenburg Coins from the $14^{\text {th }}$ and $15^{\text {th }}$ Centuries. Notae Numismaticae Zapiski Numizmatyczne 13, 137-167.

PAszKiewicz, Borys

1986 Mennictwo Władysława Łokietka. Wiadomości Numizmatyczne 30,1-2, 1-112.

2000 The Monetary Reform of King Václav II in Poland. In: [Smržová, P. (ed.):] Mezinárodní konference k 700. výročí Královského horního zákoníku "Ius Regale Montanorum" a měnové reformy krále Václava II. Kutná Hora 3.-5. říjen 2000. Sekce 3, Numismatika. Praha, 13-27.

2002a Denar Władysława Łokietka z tarczą. Wiadomości Numizmatyczne 46:1. 67-73.

2002b Zagadka denara króla Polski z końca XIII wieku. Wiadomości Numizmatyczne 46:1, 1-13.

2008 Kraków, Sandomierz i mennictwo Władysława Łokietka. In: Piech, Z. (ed.): Miasta, ludzie, instytucje, znaki. Księga jubileuszowa ofiarowana Profesor Bożenie Wyrozumskiej w 75. rocznicę urodzin. Kraków, 765-778.

2010 Nieznany denar książęcy Władysława Łokietka. An unknown ducal penny of Ladislaus the Elbow-high. Wiadomości Numizmatyczne 54:1, 87-92.

2019 Uwagi o mennictwie wielkopolskim w okresie kwartnikowym. In: Pidkova, I. (ed.): Читати писати говорити. Збірник наукових праць на пошану професора Романа Шуста. Visnyk of the Lviv University, Series History - Special Issue, 162-174. DOI: http://dx.doi.org/10.30970/his.2019.0.9843

PIECH, ZENON

2008 Herb miasta Kazimierza pod Krakowem, In: Piech, Z. (ed.): Miasta, ludzie, instytucje, znaki. Księga jubileuszowa ofiarowana Profesor Bożenie Wyrozumskiej w 75. rocznicę urodzin. Kraków, 813-861.

PTAK, JAN

2015 O rzekomej bitwie Kazimierza Wielkiego z Litwinami pod Sochaczewem w maju $1350 \mathrm{r}$. About the alleged battle between Casimir III the Great and Lithuanians near Sochaczew in May 1350). Roczniki Humanistyczne 63:2, 5-23. DOI: https://doi. org/10.18290/rh.2015.63.2-1

Rokosz, MieczysŁaw

2002 Sigillum regis... et civitatis. O pieczęci wielkiej Sandomierza. In: Biernat, A. et al. (eds): Heraldyka i okolice. Warszawa, 311321.

SIMONYI, ERIKA

2004 Középkori templom és temető Felsőzsolca-Nagyszilváson (Medieval Church and Churchyard at Felsőzsolca-Nagyszilvás). Herman Ottó Múzeum Évkönyve 43, 161-197.

2005 Középkori és koraújkori templom és temető FelsőzsolcaNagyszilváson (Medieval Church and Churchyard at Felsőzsolca-Nagyszilvás). In: Ritoók, Á.-Simonyi, E. (szerk.): „...a halál árnyékának völgyében járok”. A középkori templom körüli temetők kutatása. Opuscula Hungarica 6. Budapest, 305-314.

STRONCZYŃSKI, KAŹMIRZ

1885 Dawne monety polskie dynastyi Piastów i Jagiellonów. Part III. Piotrków.

STRóżyK, PAWEe

2017 Raz jeszcze o pieczęci wielkiej miasta Sandomierza. Roczniki Historyczne 83, 103-122. DOI: http://dx.doi.org/10.12775/ RH.2017.03

Teterycz, Agnieszka

2001 Status terytorium sandomierskiego. In: Bęc, M. et al. (eds): Sandomierz: z dziejów polityki, prawa i kultury. Sandomierz, 54-73. 
TreLIŃSKA, BARBARA

1991 Gotyckie pismo epigraficzne w Polsce. Lublin.

URZĘDNICY MAŁOPOLSCY XII-XV WIEKU.

1990 Gąsiorowski, A. (ed.): Spisy. Wrocław.

WYroZUMSKA, BożENNA

1961 Przywileje lokacyjne. In: Jędrzejewicz, J. (ed.): Radom. Szkice z dziejów miasta. Warszawa, 85-87.
WYROZUMSKI, JERZY

1992 Dzieje Krakowa. T. 1. Kraków do schyłku wieków średnich. Kraków.

ŻMUdzki, PAWEe

2000 Studium podzielonego królestwa. Książę Leszek Czarny. Warszawa.

\title{
Łokietek Ulászló (1305-1333) uralkodása alatt vert Sandomierz-denár Felsőzsolca temetőjéből
}

\author{
Borys Paszkiewicz - Simonyi Erika
}

Felsőzsolca-Nagyszilváson az 1999-2000 között folyó feltárások során a 27. sírból előkerült egy hosszú ideig meghatározhatatlan 14-15. századi, baltikumi származásúnak vélt pénz. A sírban más melléklet nem volt, így keltezése is bizonytalan lábakon állt. Közel húsz év elteltével derült fény a pénz származási helyére, az első ilyen veret ugyanis csak 2013-ban került elő Lengyelországban, Piotrówka erődjében. Napjainkig mindössze hat veretet ismerünk a típusból.

A pénz előlapján a köriratban $+\mathrm{DED} \Lambda[\mathrm{RIV}] \mathrm{S}$; felirat olvasható, a középső mezőben gyöngysorkeretben egy nagy $\mathrm{S}$ betü látható. Hátoldalán a verési helyre utaló

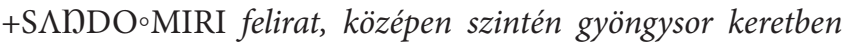
háromágú, liliomos koronát viselö sasfej látható. A Krakkótól 160 km-re, ÉK-re - a Visztula és San torkolatánál, az előbbi átkelőhelyénél, kereskedelmi útvonalak metszéspontjában - fekvő Sandomierz városa már a 12. századtól Kis-Lengyelország egyik jelentős központja volt. A denár nevében megjelenő és egyértelműen a városra utaló nagy $\mathrm{S}$, az uralkodó nevének, titulusának hiánya arra utal, hogy a zsolcai denárt különleges körülmények között verték. A várost 1305-től uraló herceget - a későbbi király I. Łokietek Ulászlót (13201333) - a város 1307 és 1311 között Sandomierz városa vonakodott elismerni. A veret ritkasága, és az, hogy kizárólag csak a városra utal, s az uralkodóra nem, amellett érvel, hogy ezekben az években verték. 1311-ben a város polgárai fel is lázadtak a herceg ellen, aki a magyar Aba Amádé támogatásával verte le az ellenállást. Valószínünek tarthatjuk, hogy az Ulászlót támogató magyar csapatok egyik résztvevőjével kerülhetett a rendkívül ritka érme Magyarországra, a felsőzsolcai temetőbe.

Open Access. A cikk a Creative Commons Attribution 4.0 International License (https://creativecommons.org/licenses/by/4.0) feltételei szerint publikált Open Access közlemény, melynek szellemében a cikk bármilyen médiumban szabadon felhasználható, megosztható és újraközölhető, feltéve, hogy az eredeti szerző és a közlés helye, illetve a CC License linkje és az esetlegesen végrehajtott módosítások feltüntetésre kerülnek. (SID_1) 
